\title{
MAIN WAYS OF IMPROVEMENTS OF EFFICIENCY OF ORGANIZATION OF THE INTERACTIVE LEARNING ACTIVITY DURING THE FOREIGN LESSONS
}

\section{Artemenko A. I.}

\section{INTRODUCTION}

The concept of "technology" is the basis for defining the essence of pedagogical technology. The word "technology" consists of two components: 1) "techno", which simultaneously means both art (skill, mastery) and craft (professional occupation, professional occupation, profession); 2) "logic" science, description. It means that the direct meaning of the term "technology" can be interpreted as a description of skillfully executed professional activity and it can be organized optimally perfect.

The concept of "technology" is used primarily in various types of research and provides a set of knowledge about the methods and means of carrying out processes that guarantee a certain result. In recent years, the term "technology" is increasingly used by researches of the organization of the learning process which deeply study the role and functions of the student in the process of learning and their interaction with other participants in the learning process ${ }^{1}$.

We can acknoledge that the learning technology means the organization of the learning process which involves a certain system of actions and interactions with other participants. The technology includs two important aspects. Firstly, the technology of teaching which describes the system of actions not only of the lecturer but of the students too. Secondly it provides the correct application of the achievement of certain results.

Thus, the structure of learning technology, or technological structure of the learning process, is a set of methods of pedagogical interaction, the consistent implementation of which guarantees the solution of pedagogical problem. Their effectiveness depends on many factors: individual and age characteristics of students and teachers, their gender, professional skills of teachers, the content of the pedagogical process, the psychophysical condition of participants, and so on. Therefore, we can assume that the use of a set of methods of interaction in the pedagogical process does not guarantee the solution of pedagogical problems, but only creates conditions

${ }^{1}$ Деркач А.А., Щербак С.Ф. Педагогическая эвристика: Искусство овладения иностранным языком. Москва : Педагогика, 1991. 224 с. 
for changing the situation of learning process. And all pedagogical tasks are related to the development of personality ${ }^{2}$.

The variety of pedagogical technologies needs their classification. The most appropriate one is to classify them according to the degree of manifestation by subjectivity, activity and independence in the creation of students. Accordingly we can distinguish two main types of pedagogical technologies: reproductive and productive.

Defining the essence of pedagogical technology of interactive learning can begin with the concept of "interactive methods". The method is defined as a way of purposeful interaction of the lecturer and studens for the decision of learning problems. The concept of interaction can be devided into two components: "inter" - between and "action" - enhanced activity.

The key concept that defines the essence of interactive methods is "interaction". Interaction is understood as direct interpersonal communication, the most important feature of which is the ability to "take on the role of another", to imagine how it is perceived by a communication partner or group, and accordingly interpret the situation and construct their own actions. Pedagogical interaction is an exchange of activities between a lecture and students in which the activity of one determines the activity of another (others). It is a process of activity when we have participants in a single time and space, which creates the possibility of direct contact between them, the presence of a common goal, the expected result of activities that meets the interests of all and contributes to the needs of everyone, planning, control, correction and coordination of actions, distribution of a single process of cooperation, the emergence of interpersonal relationships.

\section{Interactive methods as enhanced pedagogical interaction in the educational process}

The purpose of using interactive methods in the study of foreign language is to create a comfortable learning environment in which all students interact with each other. The classes provide an opportunity to discuss various problems, prove, argue their own point of view. It is an interaction between lecturer and student, which orients the individual to the development of his creative and mental abilities and communication skills.

It is important for a modern lecturer to know the latest methods of teaching foreign languages, special training techniques and techniques to optimally choose one or another method of teaching accordingly to the level of knowledge, needs and interests of students.

Interactive means that people work together and have an influence on each other. This situation implies dialogue or conversation. Therefore, these methods are aimed at the interaction between not only students and the lecturer but also with each other, it requires an active role of students in the

\footnotetext{
${ }^{2}$ Малькова 3.А. Школа и педагогика за рубежом. Москва : 1983. С. 183.
} 
learning process. The purpose of the interactive learning is to create the special conditions leading to the involvement of all students in the learning process when the participants can understand and realise everything that happens, influence each other and make their own contribution having established the friendly and mutually supportive relationship.

The interactive teaching method is the way of collective interaction of participants, logical process of the conversation, dialogue which can development personal qualities of students.

Interactive learning technologies of foreign languages are integrative system of the learning process, which provides the goals of training on the principles of co-communicativeness, expediency of implementation and mutual complementarity of interactive methods.

Defining the essence of pedagogical technology of interactive learning can begin with the concept of "interactive methods". The method is defined as a way of purposeful interaction of the lecturer and students for the decision of learning problems. The concept of interaction can be devided into two components: "inter" - between and "action" - enhanced activity".

The key concept that defines the essence of interactive methods is "interaction". Interaction is understood as direct interpersonal communication, the most important feature of which is the ability to "take on the role of another", to imagine how it is perceived by a communication partner or group, and accordingly interpret the situation and construct their own actions. Pedagogical interaction is an exchange of activities between a lecture and students in which the activity of one determines the activity of another (others). It is a process of activity when we have participants in a single time and space, which creates the possibility of direct contact between them, the presence of a common goal, the expected result of activities that meets the interests of all and contributes to the needs of everyone, planning, control, correction and coordination of actions, distribution of a single process of cooperation, the emergence of interpersonal relationships.

It is researched that interactive teaching methods contribute to optimizing the learning process for the study of a foreign language. They are intended to put mechanisms for motivation in place and increase the efficiency of teaching foreign language communication. The advantages of using interactive methods in the process of students' learning include the maximum approximation to the real conditions of professional activity, the broad autonomy of students, decision making in conditions of creative competition and the development of skills for spontaneous speech, promoting the development of organizational skills of students, overcoming the barrier between the study of language and its practical application.

\footnotetext{
${ }^{3}$ Сорокин Ю.А., Тарасов Е.Ф. Шахнарович А.М. Теоретические и прикладные проблемы речевого общения. Москва : Наука, 1979. 327 с.
} 
The introduction interactive methods of teaching foreign languages includes the formation of communicative abilities of students, as well as the development of independence of their thinking, the formation of skills to work in small groups. The lecturer needs a lot of methodological training for implementation of innovative teaching methods as an effective pedagogical tool for optimal development and professional growth of students.

Interactive teaching methods involve real situations, the use of roleplaying games, situational tasks, pair and group work.

Interactive teaching methods are based on active interaction and cooperation of participants in the educational process. Interactive teaching methods allow you to think constructively, make informed decisions, develop the ability to prove correctness positions during the discussion, to develop the skills of the listener and the speaker. Interactive training aims to create a comfortable atmosphere.

Thus, interactive methods are enhanced pedagogical interaction, mutual influence of participants of pedagogical process through the prism of own individuality, personal experience of life ${ }^{4}$.

This is a process of intensive communication between a lecturer and students (lecture - the subject of his own professional activity puts in the position of the subject of educational activities of the student). Interactive pedagogical interaction is characterized by a high degree of communication intensity of its participants, their communication, change and diversity of its types, forms and techniques, purposeful reflection. The analysis of the practice of interactive pedagogical interaction made it possible to identify its leading features and tools, including: dialogue, meaningful activities, meaningful creativity, interpersonal relationships, freedom of choice, creating a situation of success, positivity and optimism of assessment, reflection, etc ${ }^{5}$.

Interactive learning requires a multifaced type of communication when communication links arise not only between a lecture and students, but also between all students, and the lecturer becomes an equal participant in educational activities. In the process of such communication students have the opportunity to share their thoughts and feelings within a particular topic. The use of multilateral communication makes it possible to include all students in the learning process.

The process of interaction between students on the basis of multilateral communication is possible when they can create the interpersonal communication and change the communication situation.

Ситаров

B.A.

Дидактика.

Москва,

1975.

URL: http://sdo.mgaps.ru/books/K9/M7/file/2.pdf.

5 Данилович И.А. Система игровых упражнений в учебнике English through Communication для 5 класса средней школы : дис... канд. пед наук : 13.00.02. Киев, 1994. 267 c. 
In this case we can include the application of the principles of cooperative learning ${ }^{6}$.

Another important interactive method to be employed for teaching foreign languages to the students is a discussion practice. Taking part in a discussion is a significant communication situation for students, still more it demands higher language proficiency and a certain achieved level of knowledge, so it is advisable to set up such discussions at final stages of studying.

The discussion is an active method of conducting classes, designed to mobilize practical and theoretical knowledge, the views of listeners on the problem. The discussion is relevant when considering controversial issues (but in the learning process, situation of controversy of interpretations may not arise). For these reasons, it is not correct to plan lessons as discussion in advance. When discussion is a curriculum outcome, lecturers have purposes for teaching discussion, and they explicitly teach students how to be communicative. Lecturers report that they want their students to develop discussion skills for many of the same reasons that they teach with discussion. If students will engage in discussions outside of the classroom, then the possibility of students building knowledge and exploring multiple perspectives about issues also extends outside of the classroom. An additional purpose for teaching students how to engage in discussion related to citizenship education and preparing students to discuss issues.

Dialogue can involve the perception of the participants of the pedagogical process as equal partners and subjects of interaction. Dialogue in the pedagogical process is the perception of the student by the lecture as a person, as an individual. This is the right of each participant of pedagogical interaction to be creative, to express himself in various activities, to realize his potential according to his plan, his model.

Dialogic communication between lecturer and students presupposes their ability to treat each other with respect, mutual assistance in the formation of their way of thinking, their vision of the problem, their way of solving the problem.

Thought activity as an essential feature of interactive methods is the organization of intensive mental activity of teachers and students. In interactive learning, the lecturer must organize their independent cognitive activity, problem-based learning, independent performance of various mental operations by students, such as analysis, synthesis, comparison, generalization, classification, etc.

It should combine different forms of organization of students' mental activity (individual, pair, group), providing a constant process of exchange of views between participants in pedagogical interaction ${ }^{7}$.

${ }^{6}$ Деркач А.А., Щербак С.Ф. Педагогическая эвристика: Искусство овладения иностранным языком. Москва : Педагогика, 1991. 224 с.

7 Пассов Е.И. Основы методики обучения иностранным языкам. Москва : Просвещение, 1977. 214 с. 
Meaningful creativity is a process of conscious creation (creation, construction) by students and lecturers of new meanings, content of objects and phenomena of the surrounding reality within the discussed topic. It involves the perception of participants in the pedagogical process of the surrounding reality through the prism of their individuality, expression of their individual attitude to phenomena and objects of life, reflection of meaning from the standpoint of their individuality, understanding and ability to explain to others the significance of the phenomenon under study or the process, event, situation under consideration. Meaningful creativity in the pedagogical process involves not only the creation of values by participants, but also the exchange of these values, resulting in the ratio of individual values with other values, enrichment of the own meaning of the subject, phenomenon.

The freedom of choice of students and lecturers lies in their conscious regulation and activation of their behavior, pedagogical interaction, which contribute to optimal development and self-development. This is an opportunity for the subjects of pedagogical interaction to manifest their ability to activate their own behavior, the need to overcome obstacles and difficulties; willingness and ability to act independently and interact with someone ${ }^{8}$.

Creating a situation of success is a purposeful choice by the lecturer of a set of external conditions that contribute to the receipt of learners, satisfaction, manifestation.

The success in communication is a motive for self-development and selfimprovement of the students. If we want to be successful in creation of communication situation we can use various pedagogical tools, such as positivity and optimism of student assessment. The positivity and optimism of the participants' evaluation of each other's pedagogical interaction is manifested in their desire to assess the achievements of the individual positively. This is the ability of the lecturer in assessing the activities of students to emphasize the value, uniqueness, significance of the achieved result, individual achievements, the desire to note and emphasize the positive changes in student development. This is the need of the lecturer to support the human dignity of the student, the ability of comparing the achievements of one student with achievements of another.

This is a manifestation of the lecturer's positive emotions in the implementation of the assessment procedure. At the same time, it is the right of students to be independent in their communication. The research and personal experience in the use of interactive learning indicates the need to implement in the educational process of certain organizational and pedagogical conditions without which interaction is not effective. The creation of a favourable and positive psychological atmosphere in the

\footnotetext{
${ }^{8}$ Скаткина М.Н. Дидактика современной школы. Москва, 1982. 319 с.
} 
audience is necessary to motivate students to self-disclosure and the desire to cooperate with each other and with the lecturer. ${ }^{9}$

This requires the lecturer to use special tools (techniques, methods) to create and maintain such an atmosphere in the process of studying ${ }^{10}$. The next condition for the effective use of interaction is the introduction of special rules which are mandatory for all. Definition of such rules, norms of work occurs in the course of activity of the lecturer and students. If the rules are accepted and understood by students as their own, it guarantees their observance in the classroom, regardless of whether the lecturer is present or not. In addition, during the definition, the lecturer has the opportunity to offer students the rules that he considers mandatory ${ }^{11}$.

The combination of these features and conditions makes it possible to talk about the fundamental importance of pedagogical technology of interactive learning in comparison with traditional forms of its organization. Modern education requires serious attention to this training from the system of retraining of lecturers because only consistent and purposeful work on lecturer training will really help them master these modern approaches which are so important today when it comes to forming a fundamentally new type of personality. Games are an effective means of motivating learning activities in a foreign language due to the fact that they are an effective means of expanding the worldview ${ }^{12}$.

\section{Communicative games as one of the means of developing dialogic speech}

The definition of speech activity as "unity of the social individual" does not cause objections among scientists. Analyzing the relationship between the categories of social and personal in speech it should be noted that they are not opposed to each other but are closely related and complementary because all social are generalizations of personal factors in their relationship to each other and personal real exists and makes sense only in terms of interpersonal relationships and against the background of general social guidelines.

We can acknowledge that mental activity is not only personal but also individual. Individual features are manifested in the ability to see the problem situation in the formation of tasks, in the analysis and use of conditions, in the ratio of awareness and non-awareness, in the nature of emotional regulation of search, in tactics of insistence.

\footnotetext{
${ }^{9}$ Касьяненко М.Д. Педагогіка співробітництва. Київ, 1993.

${ }^{10}$ Малькова 3.А. Школа и педагогика за рубежом. Москва, 1983. 183 с.

11 Николаева С.Ю. Индивидуализация обучения иностранным языкам. Київ : Вища школа, 1982. 140 с.

${ }^{12}$ Карпова В.Н. Формирование коммуникативно-обучающих умений проведения буквенных игр на внеклассном занятии по иностранному языку: дис. ... канд. пед. Наук : 13.00.02. Киев, 1995. 252 с.
} 
Personal speech in communication is manifested in the way of reflecting in speech units the subjective attitude of a person to the phenomena of objective reality ${ }^{13}$.

Personal assumes the presence of an addressee who creates the discourse and an addressee who is physically represented and decodes the encoded speech. The personal in speech is also manifested in how the author structures the message, how he chooses lexical units and grammatical structures from all his existing speech development of semantic speech, and how he solves the problem of semantic content and compositional design. It is noted that the personality is limited only by the basic morphological and syntactic rules and it is free in oral speech.

There are two types of information in the language: a) information that is not related to the conditions of communication, but only constitutes the subject of the message; b) additional information that related to the conditions and participants of communication.

The message of the same fact of reality can take different forms depending on official, business or domestic circumstances, the social affiliation of the interlocutors and the relationship between them, the subjective emotional attitude of the speaker to the subject of the conversation and how he considers the circumstances ${ }^{14}$.

Interactive learning is close to the real working conditions of the lecturer, using of the collective experience and knowledge to develop individual speech of students. Collective discussion and evaluation of individual speech constitute a collective point of view that is more objective ${ }^{15}$. In interactive speech learning involves not only the transfer of information but also social interaction between participants in the communicative process, and provides the construction of speech text in conditions close to real communication. The lecturers take into account the communicative context between the three elements of communication - author, addressee and speech text, which must be considered in more detail.

Analysis of the communicative and cognitive knowledge of the addressee will also contribute to the development of students' skills to choose new and interesting information, appropriate presentation style and speech design.

Communicative knowledge includes the culturological aspect (knowledge of the general cultural norms of the society of which the

${ }^{13}$ Туранский И.И. Средства интенсификации высказывания в английском языке. Куйбышев, 1987. 78 с.

14 Беркнер С.С. Некоторые явления взаимодействия реплик английской диалогической речи : автореф. дис. ... канд. филол. наук : 10.02.04. Москва, 1960. 16 с.

${ }^{15}$ Смирнова Т.В. Формы групповых взаимодействий как виды упражнений в интенсивном обучении. Интенсивное обучение иностранным языкам в высшей школе. Москва, 1987. С. 65-66. 
addressee is a member), sociological (its belonging to the social personality characteristics, ideas, inclinations).

Cognitive knowledge includes:

a) "descriptive level" - knowledge that allows you to identify a person by its internal characteristics, external features;

b) "predicative level" - knowledge that allows with sufficient reliability to predict its possible behavior and point of view;

c) "explanatory level" - knowledge that helps the author to effectively modify the behavior of the communication partner ${ }^{16}$.

In the process of interactive learning of a foreign language dialogue acts as an object of observation and analysis, as an object of editing and correction, and as a product of activity. In this regard, we can divide the dialogue into the following types: dialogue - a sample, dialogue prepared by the lecturer and dialogue prepared by students ${ }^{17}$.

The first type of dialogue includes those that are offered to us in textbooks, or texts of original literature or recorded ones.

Working with these dialogues students receive the necessary information, analyze the content, structure and use of speech. Such dialogues can serve as a model for creating your own ones.

The second type includes dialogues prepared by the lecturer which can help students to create their own dialogue, process it and activate the material they have studied in communication.

The third type includes dialogues that created by students which help us to assess the level of assimilation of the material.

The analysis of games in a foreign language showed that students having entered the role, overcame the language barrier, did not hesitate to express their thoughts in a foreign language, showed creativity and independence of thinking.

It is noted that at an early stage of preparation for holding a game students have studied recommendations about the organization of the group presentation, having received distributing material. Students of the second subgroup, playing the role, are the audience of this presentation. Their task is to think through the questions to the speakers in order to be convinced of the reliability and profitability of the submitted project. It is researched that some students will prepare some of the questions in advance, and a number of questions will arise during the dialogue, which will require the students to have active listening skills. Prior to the start of the game, the lecturer informs students about the criteria for assessing their oral performances and warns that the game will be recorded on a digital video recorder so pupils

16 Беркнер С.С. Некоторые явления взаимодействия реплик английской диалогической речи : автореф. дис. ... канд. филол. наук : 10.02.04. Москва, 1960. 16 с.

17 Карпов Н.П. Особенности структуры разговорной речи. Структурные особенности разговорной речи. Иркутск, 1963. С. 5-13. 
could estimate extent of achievement of communicative competence of each participant of the game, and also the general course of the presentation. At the end of the game, a video recording, a collective discussion of the results and a joint summing up are carried out. The analysis of games in a foreign language showed that students having entered the role, overcame the language barrier, did not hesitate to express their thoughts in a foreign language, showed creativity and independence of thinking. Despite of the presence of some language errors, the communication was lively and emotional. The students demonstrated good knowledge and skills and tried to realize their significant qualities.

Cooperation between a lecturer and students is based on a sample text. Mutual learning of students in the process of group and pair work takes place through a dialogue prepared by the lecturer and creative and individual work is aimed at creating students' own dialogue. The communicative process is characterized by the possibility of one-vector or multi-vector orientation of communication. Vector communication is represented by a monologue form of communication. Dialogic speech is considered the primary natural form of speech communication compared with monologue ${ }^{18}$ which is close to real communication.

The absolute approximation of the student's actions to real professional activity has the character of a certain conventionality that includes a characteristic feature of game action. Such modeling is professionallyoriented behavior in the learning environment is due to the development of the complex various game situations, the choice of which is determined by the real professional needs of future professionals and simulated real professional conditions.

A communicative game during a foreign language lesson is used to memorize speech material and develop strong grammar skills. It has a positive effect on the activation of emotions and it contains the necessary units of dialogic speech. The game can be a good material for the introduction, consolidation and further activation of students' work with educational material ${ }^{19}$.

Communicative games have methodological value because it is interesting to conduct role-playing games for both students and lecturers ${ }^{20}$.

Communicative game is one of the components of communicative techniques. It develops the student's ability to speak the language fluently, promotes mutual understanding, increases motivation. Thus, the communicative game adds a communicative focus to educational

\footnotetext{
${ }^{18}$ Скаткина М.Н. Дидактика современной школы. Москва, 1982. 319 с.

19 Деркач А.А., Щербак С.Ф. Педагогическая эвристика: искусство овладения иностранным языком. Москва : Педагогика, 1991. 224 с.

20 Карпов Н.П. Особенности структуры разговорной речи. Структурные особенности разговорной речи. Иркутск, 1963. С. 5-13.
} 
communication, strengthens the motivation to learn English and significantly improves the quality of mastering it ${ }^{21}$.

Communicative game is a powerful factor of psychological adaptation of a student in a new speech space, which can solve the problem of natural nonviolent introduction of a foreign language into the student's world.

It should be noted that pedagogical observation allows to evaluate the effectiveness of games for the development of studentsэ dialogic skills. After all, the atmosphere of the game is quite relaxed, which provides students with tasks in a comfortable environment. This allows students to think better, develop their creative and acting skills, get involved in work, be interested during the learning process. This formulation of work with dialogues provides an opportunity to develop the necessary skills of dialogic speech ${ }^{22}$.

The most typical communicative tasks can be denial, explanation, message. Students must master the functional types of dialogues. It can be a dialoguedialogue, a dialogue-agreement, a dialogue-exchange of impressions and a dialogue-discussion. In the first type of dialogues information can belong to one partner and to each of them. Dialogue-agreement is used when the interlocutors have intentions. The next dialogue is a dialogue-exchange of impressions, the purpose of which is to present their own vision of an object, event, phenomenon, when the interlocutors express their views, provide arguments for proof, agree with point of view of the partner or refuse it. At the same time, the initiative to hold a conversation is bilateral.

The most difficult to master is a dialogue-discussion, when the interlocutors have to make a decision, to reach certain conclusions, to convince each other in something ${ }^{23}$.

In the course of communicative game in the process of learning dialogic speech various grammatical structures, intonation models, a significant amount of foreign lexical material are used. An important role is given to the unprepared speech of students. In this regard, the communicative game can surpass the capabilities of other paired group activities. Communicative game involves increasing personal involvement in everything that happens. Students unconsciously create their own reality and operate on their knowledge, developing their skills of foreign language dialogic speech.

It is note that almost all educational time in the communicative game in English classes is devoted to speech practice.We must have not only the speaker but also the listener because he must understand and remember the remark of the

21 Куліш I.M. Дидактична гра як засіб активізації навчальної діяльності студентів університету : дис. ... канд. пед. Наук : 13.00.09. Черкаси, 2001. 190 с.

22 Барановська Я. Використання рольової гри у процесі навчання діалогічного мовлення на середньому етапі. 2020.

${ }^{23}$ Птушка А.С. Методика використання рольової гри у навчанні - діалогічного мовлення учнів на уроках англійської мови. С. 154-159. 
partner, correlate it with the situation, determine how relevant it is to the situation and the task of communication and respond correctly to the remark ${ }^{24}$.

Games help the lecturer not simply practise isolated elements of grammar or pronunciation but motivate students to find out interesting information and share with each other the pieces of information needed to make up a whole dialogue.

Thus, in the process of communicative game in English classes, students develop the skills of foreign language dialogic speech, master different types of dialogues which are based on a complex system of speech skills and abilities which are formed in the process of performing a system of exercises by students ${ }^{25}$. Creating a system of using communicative games, we must proceed from the fact that in the teaching of dialogic speech there are three stages: assimilation of dialogic units by students; mastering mini-dialogues; independent compilation of students' own dialogues.

Accordingly with these stages in the system of teaching foreign language dialogic speech, there are three consecutive groups: 1) group I - exercises for learning dialogic units; group II - exercises for mastering microdialogues on the basis of mastered dialogic units; group III - exercises for composing your own dialogues of different functional types. A communicative game can be used in all three groups of exercises.

It is noted that all exercises belong to the type of conditional speech ${ }^{26}$. Within this group there are different types of exercises depending on the dialogic units that are learned, such as exercises aimed at mastering the dialogic unity of "message - message", where students take on appropriate roles such as agreement or disagreement.

As a rule all types of exercises of this group are performed in the following models: "lecturer - student", "student - lecturer", "student student". When the exercises are performed in the "lecturer - student" model, the teacher loses one of the roles.

Remarks of the lecturer are proactive, and the remarks of students are reactive. In the "student - lecturer" model, the initiative passes to students. The final for this group of exercises is the "student - student" model.

By exchanging remarks, both students play appropriate roles. Group II exercises aimed at improving students' skills of mastering dialogic units and in parallel to the development of skills to compose microdialogues. Using previously learned dialogic units, students compose microdialogues from

${ }^{24}$ Шморгун І.В. Застосування рольової гри у процесі навчання іншомовного діалогічного мовлення молодших школярів. Київ, 2016.

${ }^{25}$ Карпова В.Н. Формирование коммуникативно-обучающих умений проведения буквенных игр на внеклассном занятии по иностранному языку : дис. ... канд. пед. наук : 13.00.02. Киев, 1995. 252 с.

${ }^{26}$ Смирнова Т.В. Формы групповых взаимодействий как виды упражнений в интенсивном обучении. Москва, 1987. С. 65-66. 
two or three dialogic units. At this stage, students are offered auditory verbal supports (phonogram of the sample dialogue) and visual verbal supports (microdialogue-substitution table and microdialogue-scheme), based on the microdialogue-sample ${ }^{27}$.

\section{CONCLUSIONS}

Taking into account the above - stated, it can be concluded that the research and personal experience in using of interactive learning of foreign languages indicates the need to implement in the educational process of certain organizational and pedagogical conditions without which interaction is not effective. The creation of positive psychological atmosphere in the audience is necessary to motivate students to self-disclosure and the desire to cooperate with each other.

It is noted that games are an effective means of motivating learning activities during the foreign language lessons and is one of the components of communicative techniques. It develops the student's ability to speak the foreign language fluently.

In the process of learning dialogic speech various grammatical structures, intonation models, a significant amount of foreign lexical are included in the dialogue. The communicative game involves increasing personal involvement in everything that happens. Students unconsciously create their own reality in developing their skills of foreign language dialogic speech.

It is note that almost all educational time in the communicative games in English classes is devoted to speech practice.

In the process of communicative games in English classes, students develop the skills of foreign language dialogic speech, master different types of dialogues which are based on a complex system of speech skills and abilitieswhich are formed in the process of performing a system of exercises by students.

\section{SUMMARY}

In the scientific study, the main ways of improvements of efficiency of organization of interactive learning activity during the foreign lessons has been considered by the author. The analysis of the practice of interactive pedagogical interaction made it possible to identify its leading features and tools, including dialogue, meaningful activities, meaningful creativity, interpersonal relationships. Interactive methods are enhanced pedagogical interaction, mutual influence of participants of pedagogical process through the prism of own individuality, personal experience of life. The article deals with interactive methods of teaching of foreign languages using

\footnotetext{
27 Барановська Я. Використання рольової гри у процесі навчання діалогічного мовлення на середньому етапі. 2020.
} 
communicative games. It should be noted that pedagogical observation allows to evaluate the effectiveness of games for the development of students' dialogic skills. Communicative games as one of the means of developing dialogic speech are used in the process of teaching foreign languages. It is noted that games are an effective means of motivating learning activities during the foreign language lessons and is one of the components of communicative techniques.

\section{REFERENCES}

1. Беркнер С.С. Некоторые явления взаимодействия реплик английской диалогической речи : автореф. дис. ... канд. филол. наук : 10.02.04. Москва, 1960. 16 с.

2. Данилович И.А. Система игровых упражнений в учебнике English through Communication для 5 класса средней школы : дис. ... канд. пед. наук : 13.00.02. Киев, 1994. 267 с.

3. Деркач А.А., Щербак С.Ф. Педагогическая эвристика: искусство овладения иностранным языком. Москва : Педагогика, 1991. 224 с.

4. Скаткин М.Н. Дидактика современной школы. Москва, 1982. 319 с.

5. Карпов Н.П. Особенности структуры разговорной речи. Иркутск, 1963. C. 5-13.

6. Карпова В.Н. Формирование коммуникативно-обучающих умений проведения буквенных игр на внеклассном занятии по иностранному языку: дис. ... канд. пед. наук : 13.00.02. Киев, 1995. 252 c. URL: www.booksite.ru >fulltext $>$ trofimova1 $>$ text

7. Касьяненко М.Д. Педагогіка співробітництва. Київ: 1993. 320 с. URL: lib.otei.odessa.ua >

8. Куліш I.M. Дидактична гра як засіб активізації навчальної діяльності студентів університету : дис. ... канд. пед. Наук : 13.00.09. Черкаси, 2001. 190 с.

9. Малькова 3.А. Школа и педагогика за рубежом. Москва : 1983. $183 \mathrm{c}$.

10. Николаева С.Ю. Индивидуализация обучения иностранным языкам. Киев : Вища школа, 1982. 140 с.

11. Пассов Е.И. Основы методики обучения иностранным языкам. Москва, 1977. $214 \mathrm{c.}$

12. Смирнова Т.В. Формы групповых взаимодействий как виды упражнений в интенсивном обучении. Москва, 1987. С. 65-66.

13. Сорокин Ю.А., Тарасов Е.Ф. Шахнарович А.М. Теоретические и прикладные проблемы речевого общения. Москва : Наука, 1979. 327 с.

14. Ситаров В.А. Дидактика. Москва, 1975. URL: http://sdo.mgaps.ru/books/K9/M7/file/2.pdf.

15. Туранский И.И. Средства интенсификации высказывания в английском языке. Куйбышев, 1987. 78 с. 
16. Птушка А.С. Методика використання рольової гри у навчанні діалогічного мовлення учнів на уроках англійської мови. 2012. C. 154-159. URL: ekhnuir.univer.kharkov.ua > handle

17. Шморгун I.B. Застосування рольової гри у процесі навчання іншомовного діалогічного мовлення молодших школярів. Київ, 2016. URL: www.psyh.kiev.ua >

18. Барановська Я. Використання рольової гри у процесі навчання діалогічного мовлення на середньому етапі. 2020. DOI: 37.091.33-027.22:81'243

\section{Information about the author:} Artemenko A. I., Senior Lecturer at the Department of Foreign Languages of the Faculty of Marketing Kyiv National Economic University named after Vadym Hetman 54/1, Peremohy avenue, Kyiv, 03057, Ukraine 